\title{
An Empirical Analysis about Optimal Scale of China's Foreign Exchange Reserves
}

\author{
Tingting Cheng, Jiajie Zhu \\ Jinan University, Guangzhou, China \\ Email: jnu13535058542@126.com
}

How to cite this paper: Cheng, T. T., \& Zhu J. J. (2020). An Empirical Analysis about Optimal Scale of China's Foreign Exchange Reserves. Journal of Service Science and Management, 13, 357-376.

https://doi.org/10.4236/jssm.2020.132024

Received: March 3, 2020

Accepted: April 23, 2020

Published: April 26, 2020

Copyright (อ 2020 by author(s) and Scientific Research Publishing Inc. This work is licensed under the Creative Commons Attribution International License (CC BY 4.0).

http://creativecommons.org/licenses/by/4.0/ (c) (i) Open Access

\begin{abstract}
Foreign exchange reserves are of vital importance of in the area of international finance research. It is related to a country's ability to stabilize the currency exchange rate and balance of payments adjustment. Foreign exchange reserves are an important indicator to examine a country's foreign economic relations. Exploring the optimal scale of China's foreign exchange reserves is an important topic of academic research. This thesis firstly explores the optimal scale of China's foreign exchange reserves by using the improved Agarwal model. The result shows that the China's foreign exchange reserves are in the optimal interval in 2016. After that, the writer employs some tests to determine some variables that may have effects on the foreign exchange reserves. The test results show that the export, import, GDP, and the foreign direct investment (FDI) have co-integration with the foreign exchange reserves. And therefore these factors have the long term effects on the level of foreign exchange reserves.
\end{abstract}

\section{Keywords}

China's Foreign Exchange Reserves, Agarwal Model, Unit Root Test, Co-Integration Equation, Granger Causality Test

\section{Introduction}

From 2001, there is a rapid growth of foreign exchange reserves in China. And after February 2006, the scale of foreign exchange reserves in China exceeds that of Japan. And China becomes the country that has the largest scale of foreign exchange reserves in the world. At the end of 2016, the foreign exchange reserves had been more than 3 thousand billion. On one hand, holding a larger foreign exchange reserves can contribute to the growth of economy and avoid a larger fluctuation in domestic currency. On the other hand, holding a larger foreign 
exchange reserves has a lot of cost, such as decreasing the efficiency of the monetary policies, causing too much domestic currency in circulation, opportunity cost and so on. These drawbacks may affect the healthy growth of economy. And an insufficient foreign exchange reserve also has some shortcomings, such as the depreciation pressure of domestic currency, the weak power of intervention in the foreign exchange market and so on. So it is essential to determine whether the scale of foreign exchange reserves is in the optimal range. Now the scale of the foreign exchange reserves is declining from 2014. And many people are worried about whether there are enough foreign exchange reserves in China and whether there is continuous depreciation of RMB. Some people think RMB will depreciate for a long time and they hurry to exchange foreign currency with RMB. But some people don't think so. They believe that the scale of China's foreign exchange reserves is still in the optimal scale. What is the fact? Foreign exchange reserves are of vital importance in the area of international finance research. It is related to a country's ability to stabilize the currency exchange rate and balance of payments adjustment. So it is essential to control the foreign exchange reserves in a temperate scale. In this thesis, the writer will explore the fact about the scale of foreign exchange reserves. And the writer also explores the variables that can affect the scale of China's foreign exchange reserves. Then, according to the fact the writer finds, China's government can take some measures on these variables in order to keep the scale of foreign exchange reserves in the optimal range.

\section{Literature Review}

The exploration about the temperate scale of foreign exchange reserves dates back to 1940s in foreign countries. There are many theoretical achievements after many years' researches.

Triffin (1947), firstly came up with the ratio analysis method to measure the temperate scale of foreign exchange reserves. It is acknowledged that the proportion between foreign exchange reserves and imports can be used to determine the temperate scale. He thinks the optimal proportion between foreign exchange reserves and imports is $40 \%$. And when the proportion is lower than $30 \%$, administration of exchange control should take measures to adjust it.

Heller and Agarwal are the represent of cost \& benefit method to explore the temperate scale of foreign exchange reserves. Heller (1966) thinks holding a certain scale of reserves can cause loss while generating benefit. When the marginal cost is equal to the marginal revenue, it is optimal scale of foreign exchange reserve. And Agarwal (1971) made some adjustments and expansions to the Heller model. The modified model is designed by minimizing the cost and maximizing the revenue. The Agarwal model also takes the difference between the developing country and developed country into consideration. The model is mainly practical in developing country for the research in temperate scale of foreign exchange reserves.

R. G. Carbaugh (1976) put forward that the researchers can do qualitative analysis by investigating the six factors to analyze the demand of foreign exchange reserves. The factors include the quality of foreign exchange reserves, 
mechanism of adjustment of balance-of-payments, the altitude of adjustment by government, the cooperation altitude of each country in economic policy, the resource and stability of international liquidity, the tendency of balance of payment and the economic position of country.

Ben-Bassat and Gottlieb (1992) put forward a new model. They think the major reason of holding foreign exchange reserves is precautionary motive, especially for Asian emerging countries. After the Asian financial crisis happened in 1990s, this theory is attached more importance. It proves that the country that holds a lot of foreign exchange reserves can have full capacity to withstand financial crisis.

Disyatat (2001) considered the demand of foreign exchange reserves in terms of preventing monetary crisis. He believes, though all the researchers agree that it would use up foreign exchange reserves when stabilizing the exchange rate, there are lack of research about situation where the government choose to use up the foreign exchange reserves.

In recent years, it is very popular to explore optimal scale of foreign exchange reserves by maximizing utility. Jeanne and Ranciere (2011) are the representatives. They come up with an inter-temporal equilibrium model basing on maximizing utility.

Domestic scholars have done many researches and discussions on temperate scale of foreign exchange reserves in terms of qualitative and quantitative approaches. Their focus is the scale of foreign exchange reserves. There are three different opinions toward the current scale of foreign exchange reserves. One is excess. The second one is temperate. And the last one is inadequate. And most scholars think the scale of foreign exchange reserves is excess in China.

Liu (2000) thinks a country should hold enough foreign exchange reserves to prevent exchange rate shock. He used the ratio of the scale of foreign exchange reserves and M2 as a measurable indicator. And he got the result that the scale of foreign exchange reserves is not inadequate.

\section{Summary of Literature Review}

Foreign research is more comprehensive in exploration about temperate scale of foreign exchange reserves. They have many different methods. As for the domestic research about the reserves, most research are based on the foreign bibliography.

Comparing different approaches, the writer thinks the cost and benefit method is better, especially the Agarwal model. So in this thesis, the writer will choose the cost and benefit method to analyze temperate scale of foreign exchange reserves.

Compared to the previous research, the main contribution of in this thesis is we modified the Agarwal model according to special situations in China, we consider the factor of the scale of external debt, the foreign direct investment, the intervention of the foreign exchange market and personal foreign exchange demands when predicting the optimal scale of China's foreign exchange reserves. And the modified model is designed according to Agarwal model and 
Keynesian theory. Another contribution is that the data we used spans many years, the results can explain the current situation better and enrich the empirical study of optimal scale of foreign exchange reserves. Besides, the writer also explores the relationship between the foreign exchange reserves and some related factors. The result of the tests can illustrate a long term relationship between the factors and the scale of China's foreign exchange reserves. And China's government can make some decisions to keep an optimal scale of foreign exchange reserves according to the test results.

\section{Determining the Optimal Scale of China's Foreign Exchange Reserves}

\subsection{Definition of Foreign Exchange Reserves}

Foreign-exchange reserves (also called forex reserves or FX reserves, hereafter in the thesis, forex reserves) are money or other assets held by a central bank or other monetary authority so that it can pay if need be its liabilities, such as the currency issued by the central bank, as well as the various bank reserves deposited with the central bank by the government and other financial institutions. Reserves are held in one or more reserve currencies, mostly the United States dollar and to a lesser extent the Japanese yen.

Figure 1 shows the evolution of China's forex reserves. There are three stages in the evolution. The first stage is from 1987 to 2001. In this stage, the China's forex reserves increased at a slow rate. And after 2001, there is a repaid growth rate in China's forex reserves. This high growth rate had lasted till 2014. Then the scale of China's forex reserves is decreasing recently, which cause people's concern about the forex reserves.

\subsection{The Introduction of Agarwal Model}

H. R. Heller is the first economist to drive the optimal forex reserves using cost-benefit approach. He thinks holding the forex reserves can generate revenue while generating opportunity cost. The revenue from holding reserves in the model stems from the ability to avoid a reduction in case of a deficit in the balance of payments. The opportunity cost of holding reserves is the gap between the return on capital and reserves. When the marginal cost is equal to the

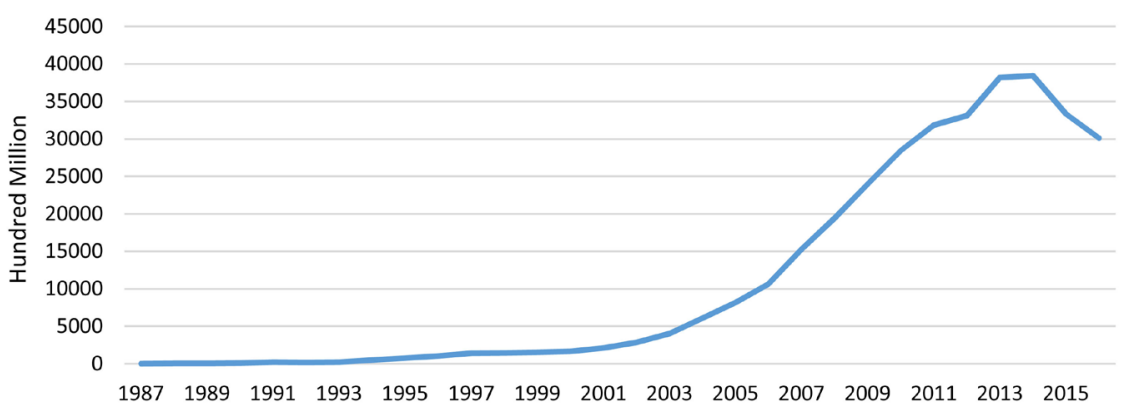

Figure 1. The evolution of China's forex reserves. Data Source: State administration of foreign exchange. 
marginal revenue of holding forex reserves, it is the optimal scale of forex reserves.

Overcoming some shortcomings of the Heller model and considering differences in system and structure between developing countries and developed countries, Agarwal (1971) built the his model in the optimal currency reserves in the developing countries. The optimal scale of forex reserves is determined according to minimizing cost and maximizing revenue. The J. Agarwal model established a standard for an optimal reserve. From one perspective, the optimal reserves should assure investors that enough capital is available when the country faces a balance of payments deficit. In addition, when the cost is equal to the income gained from holding the reserves, the reserves is at its optimal size.

$$
\text { Agarwal model: } R=W \times\left(\lg K+\lg Q_{2}-\lg Q_{1}\right) / \lg P
$$

where, $W$ is the scale of trade balance deficit. $K$ represents the reciprocal of the capital output ratio. $Q_{1}$ represents the proportion of imports of additional available capital goods. $Q_{2}$ represents the proportion of imported goods and total output. And $P$ is the probability of a balance of payments deficit.

Agarwal model is mainly useful for developing country. And in this thesis, some additions and corrections are made on the basis of Agarwal model. The writer uses the modified model to determine the optimal scale of forex reserves.

\subsection{The Modified Agarwal Model}

\subsubsection{The Modification of Agarwal Model}

In fact, the demand for forex reserves is the demand for the currency of other countries. So the writer can analyze the demand motivation of holding forex reserves according to the Keynesian monetary demand theory, which is first formulated by Keynes in 1936. Although the object in the Keynesian monetary demand theory is one person, the object in the Agarwal model is a country. The Keynesian theory also can be applied to analyze the demand motivations for forex reserves. Keynes said that money was demanded due to three main motives: 1) the transactions motive. 2) The precautionary motive. 3) The speculative motive. For one country, the forex reserves are needed to satisfy the demand for payment with other country. This kind of motive is called trading motivation. And the country also need hold a lot of forex reserves to pay off the debt on time. This is debt related motivation. According to many researchers' result and the special situations in China, the optimal scale of the forex reserves should be determined by trading reserves, debt related reserves, precautionary reserves and adjusting reserves.

Although Agarwal model has made some corrections on the basis of Heller model, it still has some drawbacks when applied to China. The model doesn't take the demand for paying off debt reserves and precautionary reserves into consideration. The model only care about the deficit balance of payment. It is inconsistent with the situations in China. At present, the scale of external debt 
is larger and larger. The foreign direct investment is also in a high level. These two factors are attached much importance to the demand for forex reserves. In addition, China should hold a part of reserves to avoid large fluctuation in the exchange rate. When taking these factors into consideration, the original Agarwal model could be modified as:

$$
R=W \times\left(\lg K+\lg Q_{2}-\lg Q_{1}\right) / \lg P+a D+b F D I+c T+d G D P
$$

where, $R$ indicates the optimal scale of forex reserves. $a D$ is the debt related reserves, $D$ is the external debt. $b$ is the foreign direct investment profit repatriation. FDI represents the foreign direct investment. $T$ is the transaction volume in the foreign exchange market. $C$ is the ratio of the amount of foreign exchange used to intervene the forex market to the total foreign exchange transactions. GDP represents the gross domestic product. $d$ is the ratio of personal foreign exchange demands account in the gross national income. $W \times\left(\lg K+\lg Q_{2}-\lg Q_{1}\right) / \lg P$ is the demand for reserves in the original Agarwal model (see Equation (3-1)). This modified model can be applied to the exploration of optimal scale of China's forex reserves.

\subsubsection{Description of Variables}

In this thesis, the writer uses the statistics from 1990-2016 to determine the scale of China's forex reserves. From 1986 to 2016, there are 31 statistics. And China's trade balance deficit appeared 4 times. The largest deficit was appeared in 1985, which was $\$ 11.9$ billion. Therefore, the writer assumes that $W$ is equal to 11.9. And $P$ is $4 / 30$ in the model. $K$ can be represented by the ratio of $G D P$ to the total investment in fixed assets. $Q_{I}$ can be denoted by the ratio of imported primary products to new investment in fixed assets. $Q_{2}$ can be denoted by the ratio of imported primary products to GDP. The debt related reserves can be measured by short term debt and long term debt. The writer assumes the average long term debt maturity is 8 years. Then the debt related reserves $R_{d}=D_{s}+12.5 \% D_{L}$ ( $D_{s}$ is the short term debt, $D_{L}$ is the long term debt).

As for the foreign direct investment profit repatriation $b$, according to the estimation of IMF, the annual rate of return of FDI is 13 - 14 percent in developing country. And now adjusting the situations in China, the $b$ should be in the range of $10 \%-15 \%$. According to the international experience, the ratio of the amount of foreign exchange used to intervene the forex market $M$ to the total foreign exchange transactions $T$ is defined at $8-18$ percent. The ratio of personal foreign exchange demands account in the gross national income is defined at $1-4$ percent. After determining the ranges of the coefficients, the optimal range of China's forex reserves can be calculated.

\subsubsection{The Estimation of the China's Optimal Foreign Exchange Reserves}

According to the modified Agarwal model, then the writer can get the range of the optimal foreign exchange reserves. The upper limit $R_{\max }$ :

$$
\begin{aligned}
R_{\max }= & W \times\left(\lg K+\lg Q_{2}-\lg Q_{1}\right) / \lg P+D_{s}+12.5 D_{L} \\
& +15 \% F D I+18 \% T+4 \% G D P
\end{aligned}
$$

The lower limit $R_{\min }$ : 


$$
\begin{aligned}
R_{\min }= & W \times\left(\lg K+\lg Q_{2}-\lg Q_{1}\right) / \lg P+D_{s}+12.5 \% D_{L} \\
& +10 \% F D I+8 \% T+1 \% G D P
\end{aligned}
$$

Table 1 shows the value of each coefficient in the model. After getting these data, the writer can get the upper limit and the low limit of the forex reserves. And to determine whether the scale of forex reserves is optimal, the actual China's forex reserves should be compared with the range of optimal forex reserves. Then the table below shows the result of comparison.

Table 2 shows the Optimal Scale of Forex Reserves and the Actual Reserves. Figure 2 can have a visual sense of the optimality of China's forex reserves. And in the figure, it is clear to see whether the scale of forex reserves is optimal in one year.

\begin{tabular}{|c|c|c|c|c|c|}
\hline Year & W (billion \$) & $\mathbf{P}$ & $\mathbf{K}$ & $\mathrm{Q}_{1}$ & $\mathrm{Q}_{2}$ \\
\hline 1990 & 11.9 & $2 / 15$ & 4.13 & 4.42 & 0.03 \\
\hline 1991 & 11.9 & $2 / 15$ & 3.89 & 0.54 & 0.03 \\
\hline 1992 & 11.9 & $2 / 15$ & 3.33 & 0.29 & 0.03 \\
\hline 1993 & 11.9 & $2 / 15$ & 2.70 & 0.16 & 0.03 \\
\hline 1994 & 11.9 & $2 / 15$ & 2.83 & 0.36 & 0.03 \\
\hline 1995 & 11.9 & $2 / 15$ & 3.06 & 0.68 & 0.03 \\
\hline 1996 & 11.9 & $2 / 15$ & 3.13 & 0.73 & 0.03 \\
\hline 1997 & 11.9 & $2 / 15$ & 3.20 & 1.17 & 0.03 \\
\hline 1998 & 11.9 & $2 / 15$ & 3.00 & 0.55 & 0.02 \\
\hline 1999 & 11.9 & $2 / 15$ & 3.03 & 1.53 & 0.02 \\
\hline 2000 & 11.9 & $2 / 15$ & 3.05 & 1.26 & 0.04 \\
\hline 2001 & 11.9 & $2 / 15$ & 2.98 & 0.88 & 0.03 \\
\hline 2002 & 11.9 & $2 / 15$ & 2.80 & 0.65 & 0.03 \\
\hline 2003 & 11.9 & $2 / 15$ & 2.47 & 0.50 & 0.04 \\
\hline 2004 & 11.9 & $2 / 15$ & 2.30 & 0.65 & 0.06 \\
\hline 2005 & 11.9 & $2 / 15$ & 2.11 & 0.66 & 0.07 \\
\hline 2006 & 11.9 & $2 / 15$ & 1.99 & 0.70 & 0.07 \\
\hline 2007 & 11.9 & $2 / 15$ & 1.97 & 0.68 & 0.07 \\
\hline 2008 & 11.9 & $2 / 15$ & 1.85 & 0.71 & 0.08 \\
\hline 2009 & 11.9 & $2 / 15$ & 1.55 & 0.38 & 0.06 \\
\hline 2010 & 11.9 & $2 / 15$ & 1.64 & 1.08 & 0.07 \\
\hline 2011 & 11.9 & $2 / 15$ & 1.57 & 0.65 & 0.08 \\
\hline 2012 & 11.9 & $2 / 15$ & 1.44 & 0.63 & 0.08 \\
\hline 2013 & 11.9 & $2 / 15$ & 1.33 & 0.57 & 0.07 \\
\hline 2014 & 11.9 & $2 / 15$ & 1.26 & 0.60 & 0.06 \\
\hline 2015 & 11.9 & $2 / 15$ & 1.20 & 0.59 & 0.04 \\
\hline 2016 & 11.9 & $2 / 15$ & 1.25 & 0.92 & 0.04 \\
\hline
\end{tabular}

Table 1. The coefficients of the modified model.

Source: China statistical yearbook, the national bureau of statistics of china, state administration of foreign exchange. 


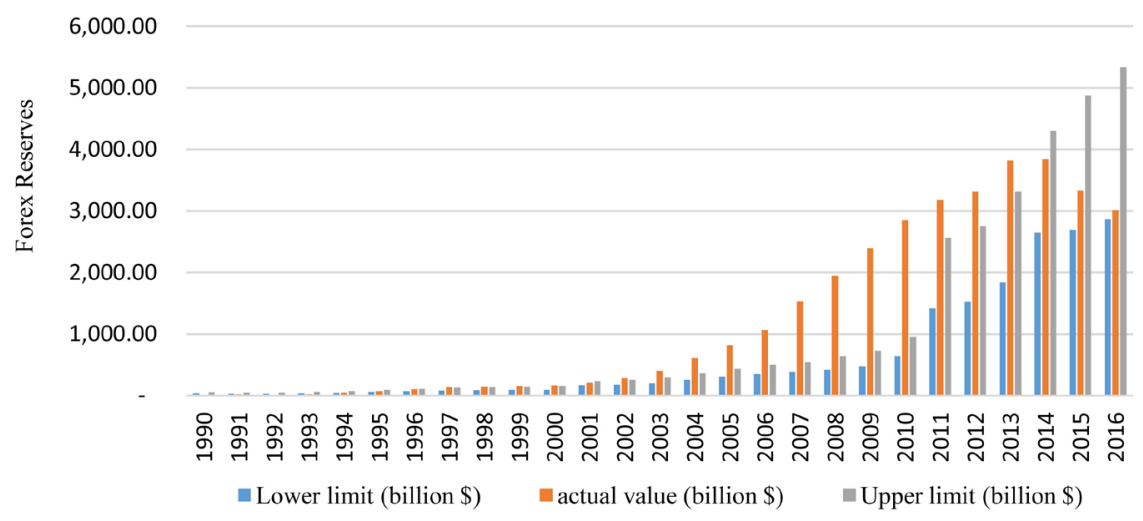

Figure 2. The optimal scale and the actual value. Source: China statistical yearbook, the national bureau of statistics of china, state administration of foreign exchange.

Table 2. The optimal scale of forex reserves and the actual reserves.

\begin{tabular}{|c|c|c|c|c|}
\hline Year & $\begin{array}{l}\text { Lower limit } \\
\text { (billion \$) }\end{array}$ & $\begin{array}{l}\text { Actual value } \\
\text { (billion \$) }\end{array}$ & $\begin{array}{l}\text { Upper limit } \\
\text { (billion \$) }\end{array}$ & Whether Optimal \\
\hline 1990 & 41.08 & 11.09 & 54.50 & Insufficient \\
\hline 1991 & 34.40 & 21.71 & 49.82 & Insufficient \\
\hline 1992 & 34.45 & 19.44 & 51.87 & Insufficient \\
\hline 1993 & 39.95 & 21.20 & 60.29 & Insufficient \\
\hline 1994 & 47.98 & 51.62 & 73.79 & Optimal \\
\hline 1995 & 61.04 & 73.60 & 96.29 & Optimal \\
\hline 1996 & 70.38 & 105.03 & 111.32 & Optimal \\
\hline 1997 & 84.41 & 139.89 & 131.25 & Excess \\
\hline 1998 & 86.97 & 144.96 & 136.29 & Excess \\
\hline 1999 & 94.28 & 154.68 & 145.49 & Excess \\
\hline 2000 & 93.92 & 165.57 & 151.71 & Excess \\
\hline 2001 & 170.28 & 212.17 & 237.51 & Optimal \\
\hline 2002 & 180.10 & 286.41 & 256.08 & Excess \\
\hline 2003 & 205.06 & 403.25 & 294.75 & Excess \\
\hline 2004 & 255.72 & 609.93 & 362.98 & Excess \\
\hline 2005 & 304.85 & 818.87 & 433.25 & Excess \\
\hline 2006 & 352.56 & 1066.34 & 506.72 & Excess \\
\hline 2007 & 387.11 & 1528.25 & 545.17 & Excess \\
\hline 2008 & 421.25 & 1946.03 & 643.56 & Excess \\
\hline 2009 & 475.48 & 2399.15 & 726.36 & Excess \\
\hline 2010 & 639.83 & 2847.34 & 953.61 & Excess \\
\hline 2011 & 1417.41 & 3181.15 & 2564.40 & Excess \\
\hline 2012 & 1522.51 & 3311.59 & 2758.16 & Excess \\
\hline 2013 & 1840.96 & 3821.32 & 3315.36 & Excess \\
\hline 2014 & 2646.10 & 3843.02 & 4308.29 & Optimal \\
\hline 2015 & 2690.51 & 3330.36 & 4874.79 & Optimal \\
\hline 2016 & 2869.67 & 3010.52 & 5335.97 & Optimal \\
\hline
\end{tabular}

Source: Calculated according to the modified model, the National Bureau of Statistics of China. 


\subsection{Result Analysis about Optimality of China's Forex Reserves}

From Table 1 and Figure 1 it finds that the forex reserves are sufficient in 1990-1993. In 1994, there is a large reform in the foreign exchange management system. The foreign exchange business is in line with the international business. And the forex reserves are increasing after that event. It is in the optimal scale in 1994-1996. And in 1997-2001, the forex reserves are excess a litter. Then the reserves is optimal again. The foreign exchange reserves are excess a lot in 2003-2013. But it is in the optimal scale in 2016. Although the public don't need to worry about the forex reserves now, the government needs to take some effective measures to keep the reserves level in the optimal range.

\section{Analysis on Factors Affecting Forex Reserves Scale}

If China's government wants to take some measures on the forex reserves in order to keep its optimality, they must determine some factors which can have some effects on the forex reserves. Then the writer will explore the factors affecting the forex reserves scale.

\subsection{The Factors Considered}

The scale of forex reserves can be affected by many factors, such as the economic environment factors, international trade factors, the global investment environment factors and so on. In this thesis, the writer chooses some important factors and does quantitative analysis about these factors.

Generally speaking, trade surplus or trade deficit can directly affect the scale of forex reserves. The amount of the exports and imports can have a large effect on the scale of forex reserves. According to the international experience, the scale of foreign exchange has a positive correlation with the exports and a negative correlation with the imports. When the export is larger, the scale of forex reserves should be larger with other conditions unchanged. And when the import is larger, the scale of forex reserves should be smaller with other conditions unchanged.

The foreign direct investment also has a high correlation with the forex reserves. On one hand, a foreign direct investment (FDI) is an investment in the form of a controlling ownership in a business in one country by an entity based in another country. If the foreign direct investment increases in one country, it can enlarge the scale of the forex reserves. On the other hand, if the foreign direct investment is larger, the foreign investors will also export some profit which is earned on the investment to their own countries. The country should hold a part of reserves to avoid the fluctuations caused by these activities.

Theoretically speaking, the amount of the external debt also can affect the scale of forex reserves. If one country has a large debt, it will need to hold enough forex reserves to pay off the debt or the interest on the debt on time. If one country isn't able to pay off the debt on time, it can cause a serious debt crisis and credit crisis in this country. The scale of the forex reserves should be ad- 
justed according to the amount of debt.

The gross domestic product of one country can influence the foreign exchange reserves as well. The increase in GDP shows that the country has a good economic environment, which attracts the investment of other countries. And the increase in GDP also shows that national income is increasing. It means that the disposable income of the resident is increasing. And the residents in that country will be much eager for holding foreign currencies, such as for travelling abroad, studying abroad and so on. So the GDP indicators can be an important factors affecting the scale of forex reserves.

The last factor the writer thinks can affect the scale of forex reserves is the foreign exchange rate system. In the development of RMB exchange rate system, the writer thinks the most important turning point is the event happened in 1994. Before 1994, there are two foreign exchange rates in China. One is called the official exchange rate, another is called market exchange rate. The official exchange rate is settled exchange rate between banks. And the market exchange rate is the trading exchange rate between banks and enterprises retained foreign exchange. And on $1^{\text {st }}$ January 1994, there is a new foreign exchange system which is based on the supply and demand in the market established in China. In the new system, the foreign exchange rate is single and floating. After 1994, there is only one exchange rate in China. As for how to test the effect of foreign exchange system on the scale of forex reserves, the writer will introduce the dummy variable. Before 1994, the dummy variable is 0 , and after 1994, the dummy variable is 1 .

Although there are many other factors affecting the scale of forex reserves, the writer only considers these factors above in the thesis. And the writer thinks the factors above can well explain the scale of forex reserves.

\subsection{Data Selection}

After determining the factors affecting the China's forex reserves, data selection is an important step. In this thesis, the writer will choose some economic variables that may affect the scale of forex reserves, such as the imports (IM), exports (EX), the external debt (DEB), foreign direct investment (FDI) and gross domestic product (GDP). And to avoid heteroscedasticity and the large fluctuation of the variables, the writer takes the logarithm of these economic variables to run some tests. The writer will use these five indicators to analyze the factor affection. The sample interval the writer chooses is from 1986 to 2015. There are totally 30 statistics in the thesis.

\subsection{Unit Root Test}

The data selected is time series variables. And for time series variables, it is necessary to exam the stationarity of the variables. In this thesis, the writer will use Augmented Dicky Fuller (ADF) unit root test to test whether the variables are stationary or non-stationary. In statistics, a unit root test exams whether a time series variables is non-stationary and possesses a unit root. The null hypothesis 
is generally defined as the presence of $s$ unit root and the alternative hypothesis is either stationary, trend stationary or explosive root depending on the test used. The results are shown in Table 3.

The Unit root result shows that these economic variables are non-stationary, but the first order differences of these variables are stationary at $5 \%$ confidence level. It can be illustrated that these variables are integrated of order 1. So the writer can do the co-integration test with these variables to exam whether there exists a long term relationship between them.

\subsection{Co-Integration Test}

In this thesis, there are five independent variables. The writer uses the Johansen test to do the co-integration test. The Johansen test is a procedure for testing co-integration of several I (1) time series. This test permits more than one co-integrating relationship so is more generally applicable than the Engle-Granger test which is based on the Dickey-Fuller (or the augmented) test for unit roots in the residuals from a single (estimated) co-integrating relationship.

\subsubsection{Determining the Lag Order in Co-Integration Test}

The Johansen test is very sensitive to the Lag order. It is essential to determine the right lag order. According to the conclusion that the optimal lag order of Johansen co-integration test is equal to the optimal lag order of unconstrained VAR model minus 1, the writer firstly determines the lag order of unconstrained VAR.

The writer uses the first lag difference variable to determine the lag order of unconstrained VAR. LFR is the first lag difference of logarithmic forex reserves. LEX is the first lag difference of logarithmic exports. LIM is the first lag difference of logarithmic imports. LFDI is the first difference of logarithmic foreign direct investment. And LGDP is the first lag difference of logarithmic gross domestic product. The results are shown in Table 4.

To find the optimal lag order in the results, the criteria is that the lag order where there are stars as many as possible is optimal. From Table 4, it can be easily found that the optimal lag order for VAR model is 4 . And the optimal lag order for Johansen test is 3. Getting the optimal lag order for Johansen test, the Johansen test should be done next.

Table 3. Unit root test result.

\begin{tabular}{ccccc}
\hline Variable & T-statistics & $\mathbf{5 \%}$ & $\mathbf{1 0 \%}$ & Integration Order \\
\hline LEX & -3.456603 & -2.97185 & -2.62512 & $\mathrm{I}(1)$ \\
LIM & -3.972617 & -2.97185 & -2.62512 & $\mathrm{I}(1)$ \\
LFDI & -14.38759 & -2.97185 & -2.62512 & $\mathrm{I}(1)$ \\
LD & -7.111114 & -2.97185 & -2.62512 & $\mathrm{I}(1)$ \\
LGDP & -3.176484 & -2.97185 & -2.62512 & $\mathrm{I}(1)$ \\
\hline
\end{tabular}

Source: The National Bureau of Statistics of China, Eviews 7. 
Table 4. The results for lag order.

\begin{tabular}{|c|c|c|c|c|c|c|c|c|}
\hline \multicolumn{9}{|c|}{.varsoc LFR LEX LIM LFDI LGDP } \\
\hline \multicolumn{9}{|c|}{ Selection-order criteria } \\
\hline \multicolumn{7}{|c|}{ Sample: 1991-2015 } & \multicolumn{2}{|c|}{ Number of obs $=25$} \\
\hline lag & LL & LR & $\mathrm{df}$ & $\mathrm{p}$ & FPE & AIC & HQIC & SBIC \\
\hline 0 & 92.3612 & & & & $6.3 e-10$ & -6.9889 & -6.92128 & -6.74512 \\
\hline 1 & 127.441 & 70.159 & 25 & 0.000 & $3.0 \mathrm{e}-10$ & -7.79525 & -7.38958 & -6.3326 \\
\hline 2 & 163.444 & 72.006 & 25 & 0.000 & $1.6 \mathrm{e}-10$ & -8.67549 & -7.93175 & -5.99396 \\
\hline 3 & 194.208 & 61.53 & 25 & 0.000 & $2.4 \mathrm{e}-10$ & -9.13668 & -8.05487 & -5.23627 \\
\hline 4 & 724.547 & $1060.7^{\star}$ & 25 & 0.000 & $9.3 e-27$ & $-49.5638^{\star}$ & $-48.1439^{*}$ & $-44.4445^{\star}$ \\
\hline \multicolumn{9}{|c|}{ Endogenous: LFR LEX LIM LFDI LGDP } \\
\hline \multicolumn{9}{|c|}{ Exogenous:_cons } \\
\hline
\end{tabular}

Source: the National Bureau of Statistics of China, Stata 7.

\subsubsection{Johansen Test}

Johansen test, named after Søren Johansen, is a procedure for testing co-integration of several, say k, I (1) time series. This test permits more than one co-integrating relationship. So it is more generally applicable than the Engle-Granger test which is based on the Dickey-Fuller (or the augmented) test for unit roots in the residuals from a single (estimated) co-integrating relationship.

From the results in Table 5, a conclusion can be found that the export, import, foreign direct investment and gross domestic product have long-term co-integration relationship with the forex reserves. And there doesn't exist long-term co-integration relationship between foreign exchange reserves and external debt. Why does it happen? It is easy to understand that there exist a long term relationship between the export, import, FDI, GDP and the forex reserves. But how to explain that the external debt doesn't have the long term relationship with the forex reserves. In this thesis, the writer thinks Johansen test exams whether there exists long-term relationship between two variables. And the external debt includes short term debt and long term debt. Currently, the short term debt must have a large influence on the forex reserves in theory. And the long term debt may not. Broadly speaking, it is not sure to say that the external debt doesn't have the long term co-integration relationship with the forex reserves. And at the end of 2015, the total external debt is about $\$ 1416.2$ billion. And the short term debt is about $\$ 920.6$ billion, which accounts for $65 \%$ of total debt. Overall speaking, the long term relationship is not evident between the foreign exchange reserves and the total external debt.

\subsubsection{Co-Integration Equations}

The results of Johansen test shows that the variables that have a long term relationship with the forex reserves are the export, import, foreign direct investment and the gross domestic product (GDP). And these variables are integrated of 
Table 5. Results of Johansen tests.

\begin{tabular}{|c|c|c|c|c|c|}
\hline $\begin{array}{l}\text { Variables } \\
\text { Chosen }\end{array}$ & $\begin{array}{l}\text { Hypothesized } \\
\text { No. of } \mathrm{CE}(\mathrm{s})\end{array}$ & Eigenvalue & $\begin{array}{c}\text { Trace } \\
\text { Statistics }\end{array}$ & $\begin{array}{l}5 \% \text { Critical } \\
\text { Value }\end{array}$ & Probability \\
\hline \multirow[t]{2}{*}{ (LFR,LEX) } & None $^{*}$ & 0.458939 & 18.61014 & 15.49471 & 0.0164 \\
\hline & At most 1 & 0.096566 & 2.640351 & 3.841466 & 0.1042 \\
\hline \multirow[t]{2}{*}{ (LFR,LIM) } & None $^{*}$ & 0.57531 & 27.08905 & 15.49471 & 0.0006 \\
\hline & At most $1^{*}$ & 0.169304 & 4.822772 & 3.841466 & 0.0281 \\
\hline \multirow[t]{2}{*}{ (LFR,LFDI) } & None $^{*}$ & 0.53294 & 22.2437 & 15.49471 & 0.0041 \\
\hline & At most 1 & 0.089926 & 2.449952 & 3.841466 & 0.1175 \\
\hline \multirow[t]{2}{*}{ (LFR,LDEB) } & None & 0.29638 & 11.39618 & 15.49471 & 0.1883 \\
\hline & At most 1 & 0.083137 & 2.256735 & 3.841466 & 0.133 \\
\hline \multirow[t]{2}{*}{ (LFR,LGDP) } & None* & 0.363305 & 16.16868 & 15.49471 & 0.0395 \\
\hline & At most $1^{*}$ & 0.156679 & 4.430613 & 3.841466 & 0.0353 \\
\hline
\end{tabular}

* denotes rejection of the hypothesis at 0.05 level. Source: the National Bureau of Statistics of China, EViews 7.

order 1. The Co-integration relationship depicts the long term equilibrium in economic system. Specifically speaking, it illustrates the long term equilibrium between two or more non-stationary time series variables. In this thesis, the writer can construct the relationship between forex reserves and the exports, imports, foreign direct investment, GDP. In this equation, the writer can analyze different effects caused by different factors to the forex reserve. And because there may exists serious multi-collinearity between GDP and other time series variables. To avoid multi-collinearity, the writer constructs two Co-integration equations. One is for GDP variable, another is for other variables. The lag order of the Co-integration equation is equal to the lag order of Johansen test.

From the results in Table 6, the writer gets two co-integration equations. One is equation between foreign exchange reserves and the imports, exports, foreign direct investment. Another is the equation between foreign exchange reserves and the gross domestic product.

Equation $^{\# 1}$ :

$$
\text { LFR1 = 1.412591 LEX - 0.31959 LIM + 0.471545 LFDI - } 4.954548
$$

Equation $^{\# 2}$ :

$$
\text { LFR2 }=0.816862 \text { LGDP }+0.116128
$$

These two equations show that the exports, foreign direct investment and GDP have positive correlation with forex reserves. With other conditions the same, when the export increases 1 percent, the forex reserves will increase 1.4 percent. When the foreign direct investment increases 1 percent, the forex reserves will increase 0.47 percent. And with other conditions unchanged, when the GDP increase 1 percent, the forex reserves will increase 0.82 percent. The equation $^{\# 1}$ also indicates that the imports have a negative correlation with the 
Table 6. The result for co-integration equation.

\begin{tabular}{|c|c|c|c|c|}
\hline 1 Co-integ & quation(s): & Log likelihood & \multicolumn{2}{|l|}{192.7557} \\
\hline \multicolumn{5}{|c|}{ Normalized co-integrating coefficients (standard error in parentheses) } \\
\hline LFR & LEX & LIM & LFDI & $\mathrm{C}$ \\
\hline \multirow[t]{2}{*}{1.000000} & -1.412591 & 0.319590 & -0.471545 & 4.954548 \\
\hline & $(0.09284)$ & $(0.08474)$ & $(0.01580)$ & $(0.05744)$ \\
\hline 1 Co-integ & quation(s): & Log likelihood & 59.34241 & \\
\hline \multicolumn{5}{|c|}{ Normalized co-integrating coefficients (standard error in parentheses) } \\
\hline LFR & LGDP & C & & \\
\hline \multirow[t]{2}{*}{1.000000} & -0.816862 & -0.116128 & & \\
\hline & $(0.31929)$ & $(3.07802)$ & & \\
\hline
\end{tabular}

Source: Eviews 7.

forex reserves. With other conditions the same, when the imports increase 1 percent, the forex reserves will decrease 0.32 percent. This conclusion is consistent with the theories above, and the result of the test can quite explain the situations in China.

\subsection{VEC (Vector Error Correction) Model}

An error correction model belongs to a category of multiple time series models most commonly used for data where the underlying variables have a long-run stochastic trend, also known as co-integration. ECMs are a theoretically-driven approach useful for estimating both short-term and long-term effects of one time series on another. The co-integration test shows that the imports, exports, foreign direct investment, GDP have a long term relationship with the scale of forex reserves. Then the writer establishes the VEC model to analyze the effects on the reserves caused by the short term fluctuations of variables. The lag order of the VEC model is equal to the optimal order of VAR model minus 1 . So according to Table 4, the lag order should be 3 . The result of the VEC model is shown below.

Table 7 is the result of VEC model for the Equation (4-2). It shows that the co-integration equation variable is not significant in the VEC model. Only are first difference of forex reserves, second difference of forex reserves, second difference of GDP and third difference of GDP significant in the VEC model. The model should only contains these significant variables. The model can be written as :

$$
\begin{aligned}
\Delta \operatorname{LFR}= & 0.40 \Delta \operatorname{LFR}(-1)-4.40 \Delta \operatorname{LFR}(-2)+1.44 \Delta \operatorname{LGDP}(-2) \\
& -1.18 \Delta \operatorname{LGDP}(-3)
\end{aligned}
$$

where, variables in the model illustrates the effect caused by the short term fluctuations of these variables. And the negative coefficient of error correction item proves that there exists a reverse correction mechanism between the fluctuation in the forex reserves and this item. And vice versa. 
Table 7. The $1^{\text {st }}$ result of VEC model.

\begin{tabular}{cccc}
\hline D_lfr & Coef. & $\mathrm{z}$ & $\mathrm{p}>|\mathbf{z}|$ \\
\hline ce1 & & & \\
L1 & -0.086 & -0.990 & 0.325 \\
lfr & & & \\
LD & 0.396 & 1.810 & 0.070 \\
L2D & -0.440 & -2.310 & 0.021 \\
L3D & 0.161 & 0.760 & 0.445 \\
LGDP & & & \\
LD & -0.139 & -0.160 & 0.870 \\
L2D & 1.443 & 1.910 & 0.056 \\
L3D & -1.182 & -1.640 & 0.102 \\
_cons & 0.067 & 0.300 & 0.763 \\
\hline
\end{tabular}

Source: Stata 12.

In Table 8, the second difference of logarithmic forex is not significant at the $10 \%$ confidence interval. And the writer drops this differential variable. Although the probability of the imports' first difference is excess $10 \%$, the probability is highly closed to $10 \%$. The writer thinks the first difference of the imports can be added in the VEC model. As for differential variables of the foreign direct investment, it can be found that all three lag differential variables are not significant at the $10 \%$ confidence interval. So the writer abandons the foreign direct variable in the model. And other error correction items are significant at the $10 \%$ confidence interval. The constant item is also not significant as well and abandon it.

So the VEC model 1 can be written as:

$$
\begin{aligned}
\Delta \mathrm{LFR}= & 0.87 \Delta \operatorname{LFR}(-1)+0.72 \Delta \operatorname{LFR}(-3)-1.43 \Delta \operatorname{LEX}(-1) \\
& -1.56 \Delta \operatorname{LEX}(-2)-1.23 \Delta \operatorname{LEX}(-3)+0.80 \Delta \operatorname{LIM}(-1) \\
& +1.14 \Delta \operatorname{LIM}(-2)+1.42 \Delta \operatorname{LIM}(-3)+\operatorname{ECM}(-1)
\end{aligned}
$$

In this model 4-1, ECM represents the co-integration model. ECM (-1) reflects the degree of short-term deviation from the long-term equilibrium relationship. And other variables in the model illustrate the effect caused by the short term fluctuations of these variables. And the negative coefficient of error correction item proves that there exists a reverse correction mechanism between the fluctuation in the forex reserves and this item. And vice versa. The result also shows that there exists time lag between the fluctuations in forex reserves and the error correction items. In terms of the influence level, the fluctuation in the export is more obvious than that of import. And also, the results also show that the fluctuations in the foreign direct investment doesn't has significant effect on the scale of forex reserves. This model doesn't take the FDI into consideration. Including the import and the export variables, the VEC model can well illustrate the fluctuation in the forex reserves. 
Table 8. The $2^{\text {nd }}$ result of VEC model.

\begin{tabular}{|c|c|c|c|}
\hline D_lfr & Coef. & $\mathrm{z}$ & $p>|z|$ \\
\hline \multicolumn{4}{|l|}{ _ce1 } \\
\hline $\mathrm{L} 1$ & -1.318 & -3.950 & 0.000 \\
\hline \multicolumn{4}{|l|}{ lfr } \\
\hline LD & 0.872 & 4.180 & 0.000 \\
\hline L2D & 0.188 & 0.610 & 0.540 \\
\hline L3D & 0.719 & 2.150 & 0.032 \\
\hline \multicolumn{4}{|l|}{ lex } \\
\hline LD & -1.428 & -2.120 & 0.034 \\
\hline L2D & -1.563 & -2.250 & 0.024 \\
\hline L3D & -1.232 & -2.090 & 0.036 \\
\hline \multicolumn{4}{|l|}{$\lim$} \\
\hline LD & 0.798 & 1.630 & 0.102 \\
\hline L2D & 1.140 & 2.310 & 0.021 \\
\hline L3D & 1.415 & 3.080 & 0.002 \\
\hline \multicolumn{4}{|l|}{ lfdi } \\
\hline $\mathrm{LD}$ & 0.142 & 0.130 & 0.090 \\
\hline L2D & -0.861 & -0.530 & 0.597 \\
\hline L3D & 0.995 & 1.120 & 0.265 \\
\hline _cons & 0.016 & 0.160 & 0.875 \\
\hline
\end{tabular}

Source: Stata 12.

\subsection{Granger Causality Test}

The time series variables that have the co-integration relationship don't mean the causal relationship between variables. Even if two variables have a high correlation, it doesn't mean that the change in one variable will cause the change in another variable. On the contrary, the variables that have no co-integration relationship in the long term may have the relationship in the short run. In this thesis, the writer runs the Granger causality test to exam whether there exists true causal relationship between variables. The Granger causality test is a statistical hypothesis test for determining whether one time series is useful in forecasting another. The data the writer used is the logarithmic value of the forex reserve, exports, imports, debt and the GDP. The sample interval is from 1986 to 2015. There is totally 30 data in the test. The optimal lag order of Granger test is equal to the lag order of VAR model. See the lag order in Table 4.

The writer tests the causal relationship between LFR and LEX, LIM, LFDI, LDEB, LGDP (Table 9).

The results show in Table 8 . Generally speaking, Granger test will test the variables with many lag orders. The lag order will start from 1 to the optimal lag order. If the test result is rejecting the null hypothesis with only one lag order, then the null hypothesis is rejected. It can say that there two variables has causal 
Table 9. The results of granger test.

\begin{tabular}{ccccc}
\hline Lag Order & Null Hypothesis & F-Statistic & Probability & Conclusion \\
\hline 4 & LEX does not Granger Cause LFR & 2.2311 & 0.1087 & Reject \\
4 & LFR does not Granger Cause LEX & 1.64578 & 0.2088 & Accept \\
4 & LIM does not Granger Cause LFR & 5.75628 & 0.0041 & Reject \\
4 & LFR does not Granger Cause LIM & 0.7266 & 0.5859 & Accept \\
2 & LFDI does not Granger Cause LFR & 2.59461 & 0.0869 & Reject \\
2 & LFR does not Granger Cause LFDI & 3.37093 & 0.0333 & Reject \\
4 & LDEB does not Granger Cause LFR & 0.69253 & 0.6073 & Accept \\
4 & LFR does not Granger Cause LDEB & 1.14371 & 0.3696 & Accept \\
4 & LGDP does not Granger Cause LFR & 2.32937 & 0.0977 & Reject \\
4 & LFR does not Granger Cause LGDP & 2.75747 & 0.0619 & Reject \\
\hline
\end{tabular}

Source: EViews 7.

relationship. The conclusion is draw at $10 \%$ confidence interval.

The conclusion in the table is drawn at $10 \%$ confidence level. It shows that the exports, imports, the foreign direct investment, GDP can indeed affect the scale of forex reserve. As far as the external debt, the Granger test shows that the debt has no effect on the scale of forex reserves. And the Johansen test also shows that there doesn't exist the long term relationship between the debt and forex reserves. The result of Granger test is consistent with that of Johansen test. So now, the writer thinks the variables in the co-integration Equations (4-1) and (4-2) can indeed affect the forex reserves. And the external debt doesn't have the significant effects on the forex reserves.

\subsection{Chow Test}

At the beginning of the factor analysis, the writer thinks the change in forex system can have effects on the forex reserves. But in the empirical analysis above, the writer didn't introduce the dummy variables in the model. To verify whether the factor can have the effects on the reserves, then the writer chooses Chow test to test it.

The Chow test, proposed by econometrician Gregory Chow in 1960, is a test of whether the true coefficients in two linear regressions on different data sets are equal. In econometrics, it is most commonly used in time series analysis to test for the presence of a structural break at a period. In this thesis, the reform in forex reserves happened in 1994 is a structural break in the test. So in order to do the Chow test, the writer runs the linear regression on the variables. But the logarithm of the variables is non-stationary. The writer can't do the regression directly. The logarithm of variables is integrated of order 1 . The stationary data can be gotten by taking first lag difference.

After getting the stationary data, the writer can run the regression test. And the empirical analysis above proves that the external debt has no effect on the scale of foreign exchange reserve. So in the regression model, there are only four factors in the model. The results of Chow test are shown in Table 10. 
Table 10. The result of chow test.

\begin{tabular}{|c|c|c|c|}
\hline \multicolumn{4}{|c|}{ Chow Breakpoint Test: 1994} \\
\hline \multicolumn{4}{|c|}{ Null Hypothesis: No breaks at specified breakpoints } \\
\hline \multicolumn{4}{|c|}{ Varying regressors: All equation variables } \\
\hline \multicolumn{4}{|c|}{ Equation Sam5ple: 19872015} \\
\hline F-statistic & 1.179620 & Prob. $F(4,21)$ & 0.3484 \\
\hline Log likelihood ratio & 5.877933 & Prob. Chi-Square(4) & 0.2085 \\
\hline Wald Statistic & 4.718480 & Prob. Chi-Square(4) & 0.3174 \\
\hline
\end{tabular}

Source: Eviews 7.

The results of Chow test shows that the null hypothesis should be accepted. And the dummy variable shouldn't be introduced in the model. The foreign exchange system reform in 1994 has no effect on the scale of forex reserves.

\section{Conclusions and Policy Suggestions}

\subsection{The Research Conclusions}

In summary, the scale of forex reserves is gradually from excess to the optimal status. In 2015, the scale of forex reserves is optimal according to the modified Agarwal model. And Johansen test, Granger causality test and chow test show that the export, import, GDP, and the foreign direct investment have co-integration with the forex reserves. And therefore these factors have the long term effect on the level of forex reserves. As for the external debt, the short term debt can have the effects on the forex reserves in the short term. The total external debt doesn't have the significant effects on the forex reserves. The Chow test shows that the foreign exchange reform in 1994 has no effect on the scale of forex reserves.

The limitation of the thesis is that there may be some other factors that can affect the scale of foreign exchange reserves. The writer only analyzes several factors in this thesis. And he hopes the researchers can avoid the deficiencies later.

The potential research direction is later that scholar can forecast the trend of China's foreign exchange reserves in the future.

\subsection{Policy Suggestions}

Although the forex reserves are in the optimal range in 2015, the scale is highly closed to the lower limit of the scale according to the modified model. And the writer thinks that the scale of forex reserves will be insufficient in the near future if China's government takes no measures. So it is essential to take some measures to keep the scale of forex reserves in an optimal range. The writer thinks the following measures can be useful to keep the scale of forex reserves in an optimal level. 
1) Contributing the export to a larger level. The test result shows that the export has a positive relationship with the forex reserves. When the export is larger, it can contribute to a high level of forex reserves. In reality, China's government has done a lot to contribute to a larger export, such as cross-border business, expanding the scale of short-term export credit insurance. Cross-border business refers to an international business activity that deals with transactions in different jurisdictions, transactions through e-commerce platforms, payment and settlement, and delivery of goods through cross-border logistics. It can help many companies that they don't have the abilities to go internationalized and sell their product abroad. With the help of the cross-border business, it will be an easy thing for these companies to expand their business abroad. And expanding the scale of short term export credit insurance also can encourage more companies to export their product and contribute to a larger export. This measure can help the small or middle sized companies to expand the market abroad.

2) Increasing the foreign direct investment can also contribute to a larger scale of forex reserves. The more investment made by foreign investors, the more forex reserves. China also has taken some steps to attract the investment from foreign countries. Free Trade Zone is one of the measures adopted by the government. The Preferential taxation policy is conducted in the free trade area, which can encourage the foreign investors or companies to establish new companies in the area. It attracts the foreign investment a lot. Now, there are many free trade areas in many cities, such as Shanghai, Guangzhou, Shenzhen and so on.

3) China should attach more importance to the quality of GDP. GDP has relationship with the scale of forex reserves. Increasing in the GDP will cause a growing increase in the forex reserves. So China should guarantee that GDP will develop with a sustainable growth rate in the future. Maintaining a sustainable GDP growth rate can also attract more investors and contribute them for a higher return for their investments in China. Emphasizing on the quality of GDP may require the change in the development concept and development approaches of GDP. A higher quality of GDP can help China attain a sustainable growth in economy. And a high quality of GDP also can help the country keep the scale of forex reserves in an optimal level.

4) Keeping a stable forex rate can help the country attain an optimal scale of forex reserves. If the forex rate fluctuates a lot in the forex market, many investors even the speculators will make transactions in the market for the gain resulting from the price differentials. The participation trading activity of investors is powerful. It can cause big changes in the scale of forex reserves. Keeping a stable forex rate is a chief requirement for attaining the forex reserves in the optimal range.

In the writers' opinion, the above approaches can be used to controll the forex reserves in an optimal level. And, of course, there must be other measures influencing the scale of forex reserves. Thus, new measures need to be further explored. 


\section{Conflicts of Interest}

The authors declare no conflicts of interest regarding the publication of this paper.

\section{References}

Agarwal, J. P. (1971). Optimal Monetary Reserves for Developing Countries. Weltwirtschaftliches Archiv, 107, 76-91. https://doi.org/10.1007/BF02706047

Ben-Bassat, A., \& Gottlieb, D. (1992). Optimal International Reserves and Sovereign Risk. Journal of International Economics, 33, 360-362. https://doi.org/10.1016/0022-1996(92)90008-8

Disyatat, P. (2001). Currency Crises and Foreign Reserves: A Simple Model. Imf Working Papers, 1, 457-466. https://doi.org/10.5089/9781451843644.001

Heller, H. R. (1966). Optimal International Reserves. The Economic Journal, 76, 296-311. https://doi.org/10.2307/2229716

Jeanne, O., \& Ranciere, R. (2011). The Optimal Level of International Reserves for Emerging Market Countries: A New Formula and Some Applications. The Economic Journal, 121, 905-930. https://doi.org/10.1111/j.1468-0297.2011.02435.X

Liu, B. (2000). The Demand on the Foreign Exchange Reserve for the Convertibility of RMB. The Study of Finance and Economics, 11.

Triffin, R. (1947). International versus Domestic Money. The American Economic Review, 37, 322-324. 